\title{
How to Establish an Urban Agriculture Ordinance ${ }^{1}$
}

\author{
Candace A Spencer, Catherine G Campbell, Anna Prizzia, and Liz Felter ${ }^{2}$
}

\section{Introduction}

Between 2008 and 2013, there was an increase of 2 million community gardens, 4 million home gardens, and 6 million households who reported participating in food gardening in the United States. ${ }^{3}$ The number of farmers' markets increased from 1,755 in 1994 to 8,284 in 2014, and community-supported agriculture (CSA) programs rose from a scant 2 in 1986 to more than 7,000 in $2015 .{ }^{4}$

This astonishing increase in activities ranging from backyard gardens to community gardens to working farms in urban vacant lots is evidence of increasing interest in activities collectively referred to as "urban agriculture" or "peri-urban agriculture." Establishing an urban agriculture ordinance can allow people to grow food on both public and private land for personal use and provides local opportunities for people to purchase food directly from producers. Urban agriculture can also include unconventional production systems, such as rooftop gardens, hydroponics, community farms, and agritourism destinations. Farm tours can be effective in showcasing unique qualities of urban farming operations. Urban agriculture can improve local economies and address local food system needs. A key benefit of establishing an urban agriculture ordinance for your community is that it specifies the types of activities that are allowed in specific zoning classifications. Codifying this information can address food system gaps and foster local food activities, such as those just mentioned, by clarifying for interested individuals and organizations precisely what types of activities are allowed. This specific guidance can mitigate potential problems between landowners, urban farmers, and neighbors.

While there are similarities in urban agriculture initiatives-most notably in promoting social capital, improving food security, and bolstering community capacity and resilience-there are important differences in the types of operations that are allowable in each municipality. These differences are often set out in the policies and regulations associated with the site, which can impose constraints on urban agriculture initiatives' establishment and operation. The type of land-ownership of the location determines the types of legal and other considerations associated with implementation and operation. For example, in some areas in the state of Florida, the land development code does not allow people to place gardens on public land. In other areas in Florida, people can have gardens on public land, but it is illegal to profit from activities on public land, so if an urban agriculture operation is placed in a public park or at a public library, it would be illegal for the gardeners to sell any of the food that they produce. If the food initiative is on private land, that land may be subject to specific zoning that does not allow growing or selling food or keeping animals. In master-planned communities, the issue may not be zoning but the communities' conditions, covenants, and restrictions (CCRs) or Homeowners' Association (HOA) policies. All the above examples of barriers to urban agriculture are the types of policies and ordinances that

1. This document is HS1327, one of a series of the Horticultural Sciences Department, UF/IFAS Extension. Original publication date March 2019. Visit the EDIS website at https://edis.ifas.ufl.edu for the currently supported version of this publication.

2. Candace A. Spencer, manager of environmental justice projects, Conservation Clinic at University of Florida; Fredric G. Levin College of Law; Catherine G. Campbell, research associate, UF/IFAS Program for Resource Efficient Communities; Anna Prizzia, Field and Fork program director and campus food systems coordinator, University of Florida; and Liz Felter, regional specialized agent IV, food systems/commercial horticulture, Horticultural Sciences Department; UF/IFAS Mid-Florida Research and Education Center, Apopka, FL 32703.

The Institute of Food and Agricultural Sciences (IFAS) is an Equal Opportunity Institution authorized to provide research, educational information and other services only to individuals and institutions that function with non-discrimination with respect to race, creed, color, religion, age, disability, sex, sexual orientation, marital status, national origin, political opinions or affiliations. For more information on obtaining other UF/IFAS Extension publications, contact your county's UF/IFAS Extension office. 
Extension agents or concerned residents may be interested in trying to change.

While the desire to implement urban agriculture projects is growing in popularity, there is a dearth of information available to help Extension agents and interested citizens fully understand the preliminary requirements, the steps that are likely to be the most difficult, and ways to make the process go more smoothly. The purpose of this document is to provide an overview of key information required to establish an urban agriculture ordinance, including how to find out what activities are currently allowed in your county or municipality, key stakeholders to include in the process, and key considerations in drafting an urban agriculture ordinance.

After providing the overview, case studies from urban agriculture initiatives in Florida provide real-world examples of the required activities, potential challenges, and beneficial partners for implementing these initiatives. A number of extensive urban agriculture manuals and guidebooks are available from national, governmental, and non-profit organizations. Resources related to the case studies and additional urban agriculture resources can be found at the end of the document so that readers can find further information specific to their interests and needs.

This document will be beneficial to Extension agents who would like to integrate community-based food initiatives in their Extension programming to help them identify the most appropriate type of initiative for their specific area, audience, and situation. In addition, this information can help local governments, food policy councils, and interested citizens understand how to implement an urban agriculture ordinance in their area by providing examples and associated resources for building a local coalition to foster a successful project relevant to their situation and goals.

\section{General Guideline for Establishing an Urban Agriculture Ordinance in a County or Municipality}

The first step to establishing an urban agriculture ordinance is to bring together the various stakeholders who can provide valuable input during the process. This step includes finding out what efforts have already been made in the area, who is working on them, and identifying city or county staff and community leaders who have been involved. Stakeholders with diverse backgrounds can inform different aspects of the ordinance, ensuring it is well-rounded, practical, and helpful. It is essential to ensure that the people who could potentially be affected by the ordinance are given the opportunity to share their views, goals, and concerns. These people include farmers, gardeners, and organizations involved in local food. The stakeholders should identify the overall goal and decide the activities that the ordinance will allow, prevent, and govern. It is necessary to consider whether the desired change will happen at the county or municipal level because that determines which resources to use and which local government official(s) to contact. The assistance and support of the local government is critical for the success of the ordinance, so it is important for stakeholders to form a partnership with local government officials and work together early in the process. The "Suggested Partners and Contacts" listed in the Resources section can serve as a guide for stakeholders, and the local Extension office may be able to provide additional information.

Next, stakeholders should become familiar with terminology and procedures related to urban agriculture, which are covered in the Definitions section of this document. Stakeholders should examine the land development code to see where agriculture is a permitted use-a use that does not require any action on the part of the land user to be allowed - and the overlap between those areas and the areas desired for agriculture use. If planners and stakeholders identify areas where local urban food systems development could be enhanced by an ordinance, they should work together to build understanding of the issues among staff, city council or county commission, and food system stakeholders.

The following step is to draft the ordinance language or establish a schedule to meet with local officials as they draft the ordinance. The drafters should refer to the general outline of what the ordinance should allow, prevent, and govern and use the outline to help define the permitted, conditional, and accessory urban agricultural uses.

Drafting considerations include:

- Access to site/locks

- Access to and availability of potable water

- Accessory structures

- Aesthetics and upkeep

- Clause to dissolve

- Compliance with the American Disabilities Act to ensure access for all citizens

- Days/times of operation 
- Disclaimer that the ordinance does not conflict with the Florida Right to Farm Act

- Fertilizer use and runoff

- Land ownership

- Liability

- Livestock

- Lot setbacks

- Parking

- Pesticide use and runoff

- Potential time limits for agriculture use on property

- Replanting after use ends

- Required lot size for each use, if any

- Required permits or applications

- Retail sales

- Rules of operation

- Signage

- Soil quality or testing requirements

- Vehicles (number and size) allowed

After drafting, the permitted, conditional, and accessory uses can be inserted into each zoning district. For example, in areas zoned as residential, home gardens can be added as a permitted or accessory use so that homeowners can have a garden without getting any special approval, but a market garden-where the harvested plants are sold—can be added as a conditional use, which means that type of use would require additional approval. Once the drafting process is complete, the ordinance must go through the approval process by the appropriate local governmental officials, such as a review by the city land development review board or approval by the county commission. Once the ordinance is enacted, the stakeholders should consider if there are any supporting documents that need to be drafted.

\section{Case Studies}

The selected case studies offer different examples of the process of enacting an urban agriculture ordinance in a county or municipality in the state of Florida. The information in the case studies was gathered from stakeholder interviews and news articles. Citations for those sources can be found in the Resources section of this document.

\section{New Port Richey \\ BACKGROUND}

The roots of the New Port Richey urban agriculture ordinance go back to a guerilla garden - a garden that is located on land that the gardener does not own nor has permission to garden on-that began at Simms Park, a public park owned by the city. There was a lack of information about how to establish a permanent garden at the park, so the effort to do so was hindered by confusion and ultimately was unsuccessful. The garden did not last, but the community interest in the project caught the attention of the chair of the New Port Richey (NPR) Environmental Committee (EC). The NPR EC, a city board, began to explore the idea of community gardens and did substantial research into existing community garden ordinances, how the ordinances operate in other cities, and the potential value of such an ordinance. Subsequently, the NPR EC met with the city manager and city council to discuss the idea and, with the assistance of the New Port Richey development director, the community garden ordinance was enacted in 2013. The ordinance allows for community gardens on publicly owned lots and is the predecessor to the urban agriculture ordinance.

In 2016, the NPR EC led the process of drafting an urban agriculture ordinance. The goal of the urban agriculture ordinance was to allow vacant, publicly owned lots to be used for microfarms. After collaborating on the drafting process with the city's senior planner, the ordinance was heard by the NPR Land Development Review Board (LDRB). The ordinance was not favorably received by the $\mathrm{LDRB}$, for reasons stated in the Challenges section, and the board voted against recommending the ordinance to the city council. However, the city council still heard and voted on the ordinance.

The ordinance had support from the mayor, city council members, and the community. The local government officials saw the ordinance as a measure that fit the city's goal of being progressive and forward-thinking, was favored by residents, and was generally a good idea. The hearing was well attended, and several attendees spoke in favor of the ordinance. The ordinance passed unanimously, and a comprehensive plan amendment, which included urban agriculture in the city's future land use policies, was also passed.

\section{INVOLVED PARTIES}

City officials, the NPR EC, and the community were involved in the process of enacting the urban agriculture ordinance. The ordinance was a natural complement to the 
many environmental practices that were already in place in the city, so the city's involvement was an expected inclusion. The city's development director and senior planner drafted the ordinance and welcomed the NPR EC into the drafting process to ask questions and review drafts. The city officials also clearly communicated with the NPR EC throughout the drafting process. The city attorney had final approval power over the final document.

Community feedback was gathered during the two public hearings on the ordinance and was also critical to the successful passing of the measure. There was a community consensus on the ordinance, and it had a number of supporters.

\section{ABOUT THE ORDINANCE}

The ordinance allows for the commercial sale of produce from local gardens in residential, commercial, and industrial zones. Sales in residential areas are restricted to every six months from a particular location and require a permit, which allows sales for 72 hours. This process is similar to the process for hosting garage sales in the city. The ordinance does not allow urban agriculture in mobile home parks or indoor growing operations except in areas zoned for light industrial use. Livestock is banned everywhere in New Port Richey, but the ordinance does not specify whether chickens are allowed or not. The NPR EC is responsible for applications under the ordinance.

\section{RESOURCES}

While the city doesn't provide technical support for citizens operating under the urban agriculture ordinance, the fact that the city advanced the ordinance and the nature of the ordinance is considered as its support. For example, the ordinance is permissive rather than restrictive, does not require an application fee, and is not complicated to follow.

For the past three years there has been a proposal for the city to fund a garden facilitator. The garden facilitator would compile and distribute resources on gardening and urban agriculture. Currently, the NPR EC fills this role, but the committee members are volunteers, so keeping up with the requests is difficult. The city council recently received the recommendation again but did not take action on it.

NPR does have a grassroots network of people in urban farming and gardening who can assist residents seeking to implement the urban agriculture ordinance. The weekly Tuesday morning farmers' market focused on local food offers a lively exchange and informal network for new urban farmers. At least two nonprofit organizations also provide assistance.

\section{CHALLENGES}

The LDRB's denial of recommendation was the only significant challenge to the ordinance. The stakeholders involved in drafting the ordinance believe that the denial was primarily due to limited knowledge about urban agriculture and an unwillingness to vote for the measure without full understanding of its impacts. This challenge was overcome for the city council hearing because the NPR EC educated councilmembers on the ordinance prior to the hearing.

While not a challenge, a significant factor of the drafting process was time. It took time to draft an ordinance that balanced the desires of the community with the practical considerations of city officials. It also took time to adapt model ordinances to fit the NPR community. Additionally, the small number of staff working on the ordinance contributed to the time it took to complete the process. The city considered contracting an external planner, but it was important that the drafter understood the local character and values, so the city's senior planner did the majority of the drafting.

\section{OUTCOME}

The impact of the ordinance has been modest and is mainly shown by the increase in residential gardens. Many gardens are now visible in yards in the city. A new community garden has been established since the enactment of the ordinance, and an application for a microfarm has been submitted.

\section{TAKEAWAYS}

Stakeholder collaboration is a crucial part of the successful enactment of an urban agriculture ordinance. Additionally, an entity similar to the NPR EC, such as a land conservation board or related local government committee, is recommended. The NPR EC was an important part of the process because the committee is environmentally focused, serves as a base for community discussion and ideas, and has experience with local government.

Citizen support of the ordinance is also necessary. Citizens and the local government need to be willing to work together and should address the questions of who is responsible for providing services under the ordinance and the role of citizens in those services. 


\section{Pasco County BACKGROUND}

In 2013, the county developed the Harbors - West Market Redevelopment Plan to guide revitalization efforts in that community. The Plan listed urban agriculture as a way to encourage environmental stewardship, economic prosperity, and social responsibility and was a foundation for the creation of the urban agriculture ordinance. Around that time, a report showed that $14 \%$ of Pasco County, as with other counties in Florida, was food insecure. Additionally, New Port Richey, located in Pasco County, enacted an urban agriculture ordinance in June 2016, as discussed above.

A group of Pasco County governmental employees, Extension agents, and several citizens rallied to establish a Food Policy Advisory Council (FPAC) for Pasco County. The FPAC was formed in 2016 and housed within the Pasco County government as a Board of County Commission Citizen Advisory Board. The Council began advocating for urban agriculture legislation so that residents seeking to start community gardens or community farms could do so without running into regulatory trouble. A county planner and county attorneys worked with the FPAC to draft the ordinance, which was approved by the county commission on June 20, 2017.

\section{INVOLVED PARTIES}

The UF/IFAS Pasco County Extension director, Pasco County officials, a New Port Richey resident, and the FPAC were all involved in the process of enacting the ordinance.

\section{ABOUT THE ORDINANCE}

The ordinance allows three categories of urban agricultural initiatives: community gardens, market gardens, and community farms. Home gardens are not regulated under the ordinance. Residents must submit an application to obtain a garden plan permit to implement one of the three initiatives. Accessory structures require an additional site plan, and community gardens and community farms must register with the Pasco County Planning Department. Under the ordinance, all three categories can be located on vacant property and will be the principal use until the property is developed. However, community gardens are the only type allowed on public lands.

The initiatives are distinguished based on the sale of products, vehicle trips, and size. Community gardens allow the growing and harvesting of food crops or ornamental plants on lots of any size and between 14-100 daily vehicle trips. Market gardens must be less than 5 acres and permit the sale and purchase of produce (including fruits, vegetables, and other garden-derived edibles) grown on- or off-site and more than 14 daily vehicle trips. Community farms can grow produce (including fruits, vegetables, and other garden-derived edibles) primarily for off-site distribution, have 14 or more vehicle trips daily, and be any size. Community farms also require a farm manager. Hours of operation for all the initiatives are between sunrise and sunset. If there are sales to the public, the garden/farm owner or manager must participate in an annual food safety program recommended by UF/IFAS.

\section{RESOURCES}

The UF/IFAS Extension Pasco County office offers extensive knowledge and resources to county residents through Extension agents and programming on topics like community gardens and urban horticulture.

\section{CHALLENGES}

There were procedural and substantive challenges. Procedurally, the collaboration of the FPAC with the county's legal team and Long Range Planning Department required educating the local government officials. Additionally, the FPAC is under the Government-in-the-Sunshine Law, a law designed to give transparency to government proceedings, which greatly slowed down the process. Another challenge was ensuring harmony between the urban agriculture ordinance and other aspects of the lengthy Pasco County Land Development Code.

Substantively, drafting the Definitions section of the ordinance was the most time-consuming part of the process. Identifying the discrete categories of urban agricultural uses required balancing the goal of allowing urban agriculture with the necessary legal restraints and common residential concerns of noise and traffic.

\section{OUTCOME}

In the year since the ordinance was passed, it has not yet been fully implemented. While there have been several inquiries, the garden permit application was never released. At the time of this writing, the application has been drafted and is being updated. The Comprehensive Assessment and Review for Long-Term Care Services (CARES) program runs a community garden in Elfers, located in Pasco County, and the UF/IFAS Extension Pasco County-One Stop Shop in Dade City has a farmden (a combination of a farm/garden) that is extensively used by the Extension office. 


\section{TAKEAWAYS}

Frequent communication between stakeholders during the drafting process is important, as is sustained stakeholder involvement. Also, thorough research prior to beginning the drafting process is recommended. The incorporation of the county's Planned Developments are a specific consideration that should be incorporated into the drafting process.

Some key considerations when drafting the ordinance are parking and ADA accessibility for sites, liability, access to potable water, and possibly a demonstration site to show the impact of urban agriculture. Finally, keeping the ordinance simple is advised.

\section{Gainesville}

\section{BACKGROUND}

Gainesville has an active local food community, from restaurants that source food from local farms to multiple active farmers' markets. In the last few years, momentum has built around the local food movement and improving the resiliency of the local food economy in the area. Gainesville recently gained a new commercial kitchen incubator, run by the nonprofit Working Food, and a new city commissioner who is focused on bringing healthy, affordable food to residents with limited access. The city also has a thriving network of school and community gardens. This momentum has led to conversations on how to continue encouraging a vibrant local food system, particularly as the city begins the process of updating the comprehensive plan. Concurrently, Alachua County, which includes Gainesville, is updating its comprehensive plan and seeking to include local food considerations. Building on this momentum, Working Food approached the University of Florida Levin College of Law Conservation Clinic and the UF/IFAS Field and Fork Program to research the current legal status of urban agriculture in Gainesville.

Student associates in the Conservation Clinic researched best management practices for urban agriculture and combed through Gainesville's land development code (LDC) to see where agriculture was a permitted use. The student associates then met with a city planner to discuss options for adding urban agriculture to the LDC. At the suggestion of the city planner, the student associates began to research urban agriculture ordinances and draft language for an ordinance to include urban agriculture in the LDC.

In the drafting process, the specific needs and structure of the community have been the focus. Other ordinances, like the above-discussed Pasco County urban agriculture ordinance, have been a resource, but it has been important to draft an ordinance that addresses the particular needs in Gainesville, the technical aspects of agriculture, and the potential concerns of residents. At the time of publication, discrete urban agricultural uses and the accompanying design, operational, and maintenance standards have been defined and drafted by a student associate with the consultation of the UF/IFAS Field and Fork program director and campus food systems coordinator. After reviewing the draft with a city planner and determining which zoning districts would allow certain uses, the draft was finalized and submitted to the city planner for proposal to the city commission. At the time of publication, the ordinance has not been proposed.

\section{INVOLVED PARTIES}

In addition to Working Food, the Conservation Clinic, and UF/IFAS Field and Fork, a city planner in the Gainesville Department of Doing - which houses the planning and building departments-has been instrumental to drafting the ordinance. Other stakeholders that have been peripherally involved and will be an important part of the vetting and approval process are the economic development office of the county, the assistant city manager, citizens, community education organizations that have food- and garden-based programs, and city commissioners who are part of a community food systems stakeholder group that was formed by the city.

\section{CHALLENGES}

One challenge was how to structure the different categories of urban agriculture uses. The initial plan was a structure of numbered categories and to stack these categories such that as numbers increased, so did the number of allowed uses. For example, Use 2 allowed all of the permitted activities of Use 1 plus additional activities. However, this structure tends to encourage residents to use the most permissive category allowing the most activities, rather than the category that is most appropriate for their desired activity. At the advice of the city planner, the ordinance structure was changed to have discrete categories that could be plugged into different land-use zones. Once this approach was decided, the next challenge was developing definitions for each discrete category that would capture the intended uses, while also considering current legal constraints in the code and common residential concerns of noise, smell, and traffic.

\section{TAKEAWAYS}

The most important lesson was understanding the stakeholders involved in local food. Getting feedback and support from these individuals was and will continue to 
be critical to the successful drafting and adoption of the ordinance. Timing is also a critical takeaway from this process. Having a supportive city and county leadership and the momentum of community food systems work already in motion provides more engagement and buy-in for the concept of urban agriculture.

\section{Resources}

\section{New Port Richey}

DeChant, Dell (former Chair of the New Port Richey Environmental Committee) in discussion with the lead author, July 2018.

Manns, Debbie (New Port Richey City Manager) in discussion with the lead author, July 2018.

Napper, Robert. "New Port Richey Approves Urban Agriculture Ordinance, Including Residential Sales." Tampa Bay Times, June 22, 2016. Accessed June 22, 2018. http:// www.tampabay.com/news/localgovernment/new-portrichey-approves-urban-agriculture-ordinance-includingresidential/2282677

Reiley, Laura. "Urban Farming Takes Root in New Port Richey Front Yards.” Tampa Bay Times, March 26, 2017. Accessed June 22, 2018. https://www.tampabay.com/ features/food/general/urban-farming-takes-root-in-newport-richey-front-yards/2317461

\section{Pasco County}

Elmore, Whitney (Pasco County Extension Director) in review of draft, October 2018.

Newberry, Laura. "Unused County Property in Pasco Could Soon Sprout Community Gardens." Tampa Bay Times, June 22, 2017. Accessed June 22, 2018. http://www.tampabay. $\mathrm{com} /$ news/localgovernment/unused-county-property-inpasco-could-soon-sprout-community-gardens/2327946.

Planning Department in discussion with the lead author, May 2018.

\section{Local Government Documents}

\section{Land Development Code}

- https://www.municode.com/, go to Library, select state then city or county

- Local government's website, usually in the Department of Planning
2. Comprehensive Plan

- Local government's website, usually in the Department of Planning

Note: The Department of Planning could also be called Growth Management or be broken up into Long-Range and Short-Term Planning. The Land Development Code is usually found in the Long-Range Planning section.

\section{Policy}

Putting Local Food Policy to Work for Our Communities, $2^{\text {nd }}$ edition, Harvard Law School Food Law and Policy Clinic. An in-depth legal guide to local food policy. https:// www.chlpi.org/wp-content/uploads/2013/12/good-foodgood-laws_toolkit-10.23.2017.pdf

Seeding the City: Land Use Policies to Promote Urban Agriculture, National Policy \& Legal Analysis Network and ChangeLab Solutions. Good overview of land use policies with great examples of model language for a comprehensive plan amendment and zoning ordinance. http://changelabsolutions.org/sites/default/files/Urban_Ag_SeedingTheCity_FINAL_\%28CLS_20120530\%29_20111021_0.pdf

\section{Technical Assistance}

Urban Agriculture Toolkit, United States Department of Agriculture. Overview of federal and community resources for a variety of aspects of urban agriculture. https://www. usda.gov/sites/default/files/documents/urban-agriculturetoolkit.pdf

Urban Agriculture, United States Department of Agriculture. Topic home page with links to other resources. https:// www.nal.usda.gov/afsic/urban-agriculture

\section{Planning}

Land Use Planning and Urban/Peri-Urban Agriculture, Centers for Disease Control and Prevention. Resources on the role of planners in urban agriculture and examples of assistance planners can provide. https://www.cdc.gov/ healthyplaces/healthtopics/healthyfood/landuse.htm

Policy Guide on Community and Regional Food Planning, American Planning Association. Policy guide to help planners contribute to local food policy. https://www.planning. org/policy/guides/adopted/food.htm 
Principles of a Healthy, Sustainable Food System, American Planning Association. https://www.planning.org/nationalcenters/health/foodprinciples.htm

Food Entrepreneurship Toolkit: Best Practices for Regulating Food Uses, Nieves-Ruiz, Luis. https://www.slideshare. net/luisnvrz/food-zoning-toolkit-94899091

\section{Partnership with Local Government}

Community Food Production: The Role of Local Governments in Increasing Community Food Production for Local Markets, Growing Food Connections. Overview and examples for local governments getting into local/community food production. http://growingfoodconnections. org/wp-content/uploads/sites/3/2015/11/GFCFoodProduct ionPlanningPolicyBrief_2017August29.pdf

Dig, Eat, and Be Healthy: A Guide to Growing Food on Public Property, ChangeLab Solutions. http://www. changelabsolutions.org/sites/default/files/Dig_Eat_and_Be_ Happy_FINAL_20130610_0.pdf

Creating a Common Language, Growing Food Connections. Definitions of commonly used terms in agriculture and food systems. http://growingfoodconnections.org/ wp-content/uploads/sites/3/2013/06/CommonLanguage_ AFT_GFC_Community-Guide_lo_res_11.2017.pdf

Urban Agriculture Handbook. Overview, strategies, and resources from the City of St. Petersburg and Forward Pinellas. http://forwardpinellas.org/wp-content/uploads/2018/06/Urban-Agriculture-Handbook-June-2018. pdf

\section{Sample Urban Agriculture Ordinances or Ordinances for Specific Activities}

Pasco County Urban Agriculture Ordinance: http:// www.pascocountyfl.net/DocumentCenter/View/30497/ Urban-Agriculture-Ordinance-Sent-to-State-06232017

Atlanta Urban Agriculture Ordinance: https://static1. squarespace.com/static/5810d4f2d482e9e1f1211dfa/t/5 9ef441ba8b2b0ccebf09b11/1508853056492/Urban+Ag Ordinance+No14-9-1092.pdf

\section{Pollinator-friendly landscaping and vegetation code:}

Coon Rapids, Minnesota, vegetation and landscaping code. https://library.municode.com/mn/coon_rapids/
codes/code_of_ordinances?nodeId=TIT8HESASA_CH8500MAVELA_8-503PRACNU

\section{Compost and manure policy:}

Hartford, Connecticut, Health and Sanitation Code: Includes specific policies related to manure and compost heaps https://library.municode.com/ct/hartford/codes/ code_of_ordinances?nodeId=PTIIMUCO_CH17HESA_ ARTIINGE_S17-3MACOHE

\section{Food producing animal policy:}

Denver's Food Producing Animal (FPA) Ordinance contains a policy statement from Denver for Food Producing Animals, with suggested care practices and local resources. Contains some basic information about the animals, what to expect, how to handle them, and what resources and structures are required (e.g., what kind of fencing is needed for chickens?). https://www.denvergov.org/content/dam/ denvergov/Portals/682/documents/Animal\%20Protection/ FPA\%20Best\%20Practices\%20Handout\%20-\%20EV.pdf

\section{Municipal code regarding regulation of community gardens and produce sales:}

Wauwatosa, Wisconsin, Community Garden Code allows for on-site sales or donations provides that retail sales or agricultural product sales are currently an allowed use based on the zoning of the location or if they may be allowed as a temporary use. Requires that the operator keep the property in productive use in the growing season. https://library.municode.com/wi/ wauwatosa/codes/code_of_ordinances?nodeId=TIT24ZO_ CH24.09SUUSRE_24.09.080COGA

\section{Vacant lot policies:}

City of Lawrence: Common Ground: A community gardening and urban agriculture program that was created by the city of Lawrence in Kansas in which the city leases vacant or under-utilized properties to citizens for free provided that the citizens use the land to grow food. There is an incubator farm on the edge of town which has low-cost rentals for new market growers. https://lawrenceks.org/ common-ground/

Baltimore's Urban Agriculture Tax Credit policy, which gives owners a tax credit for allowing their vacant lots to be used for urban agriculture activities. See p. 67, here: http:// ca.baltimorecity.gov/codes/Art\%2028\%20-\%20Taxes.pdf 
Link to the Application for the Baltimore City Urban Agricultural Property Tax Credit: Baltimore UrbanAgriculture-tax-credit-application.docx

\section{Definitions}

Accessory Use: an activity or function that is incidental to, and on the same lot as, a principal use. ${ }^{5}$

Comprehensive Plan: a blueprint for future commercial and residential land uses, housing, and conservation, as well as cultural and recreational amenities and transportation. ${ }^{6}$

Conditional Use/Special Use: a land use that is restricted in some way, usually in location or manner of operation, and allowed only under certain conditions. Example: a city can restrict the time, place, and manner in which liquor stores operate. ${ }^{7}$

Conditional Use Permit/Special Use Permit: the document that gives the applicant approval for the restricted use.

Future Land Use Element (FLUE): the section of the Comprehensive Plan that defines areas of the city or county that are appropriate for different land uses over a period of time, establishes the different land uses, and sets the policies to guide those uses. ${ }^{8}$

Future Land Use Map (FLUM): the visual representation of the Future Land Use Element.

Land Development Code: collection of zoning, subdivision, and other regulations that implement the policies of the Comprehensive Plan. ${ }^{9}$

Lot Setback: a distance from a curb, property line, or structure within which building is prohibited. ${ }^{10}$

Ordinance: a law passed by a municipal government, such as a city or town. ${ }^{11}$

Overlay District: a zoning district that is applied over one or more already established zoning districts and that requires additional or stricter criteria in addition to those of the underlying zoning district. Often used to protect unique community features like historic buildings or wetlands. ${ }^{12}$

Permitted/Principal Use: the main use for a parcel of land, which does not require any action on the part of the land user to be allowed.
Planner, City/Urban: a professional who develops land-use plans and programs that help create and improve communities and accommodate population growth. ${ }^{13}$

Urban Agriculture: the production of food for personal consumption, education, donation, or sale, including associated physical and organizational infrastructure, policies, and programs within urban and suburban environments. ${ }^{14}$

Variance: a waiver that allows a deviation from current zoning requirements. The waiver is specific to that applicant and is not a change in the law. ${ }^{15}$

Zoning: a method utilized by local governments of designating permitted uses of land based on mapped zones, which separate incompatible land uses from one another. For example, zoning helps to separate industrial uses from residential uses. ${ }^{16}$

Zoning Code: local laws that specify which uses are permitted in each zone and the standards that apply to each use. $^{17}$

\section{Suggested Search Terms ${ }^{18}$}

A general and specific term search of the applicable comprehensive plan and land development code is recommended to determine existing policy on urban agriculture and related topics. A specific term search is done by putting the search term in quotation marks and will only yield results with that exact phrase.

- Agriculture

- Community garden

- Community supported agriculture

- Compost

- Farm

- Farm to school

- Farmers' market

- Farming

- Farmland

- Food

- Food access

- Food distribution

- Food garden

- Food miles

- Food processing 
- Food production

- Food safety

- Food security

- Food system

- Food waste

- Foodshed

- Garden

- Healthy food

- Hunger

- Kitchen incubator

- Local food

- Locally grown

- Market garden

- Organic

- Organic farm

- Organic market

- Urban agriculture

- Urban farm

\section{Suggested Partners and Contacts}

All the suggested partners and contacts may not be relevant to a specific county or municipality but are provided for reference.

- Community Gardens-Existing Gardens or Community Garden Contact

- County Property Appraiser

- County/Municipality Central Permitting Department

- County/Municipality Economic Development Office

- County/Municipality Growth Management Department

- County/Municipality Planner or Comprehensive Plan Contact

- Farmers or local farmer organizations

- Food Policy Council

- Grassroots community organizations working in food, health, or conservation

- Public Health Department
- Regional Planning Councils

- School Garden Program Manager

- UF/IFAS Extension

\section{References}

${ }^{3}$ National Gardening Association (2014) Garden to Table: A 5-Year Look at Food Gardening in American accessed September 11, 2018 at https://garden.org/special/pdf/2014NGA-Garden-to-Table.pdf

${ }^{4}$ United States Department of Agriculture, National Agricultural Statistics Service (December 2016) 2012 Census of Agriculture Highlights, Direct Farms Sales of Food: Results from the 2015 Local Food Marketing Practices Survey (ACH12-35) Accessed February 4, 2019 at: https://www.nass.usda.gov/Publications/Highlights/2016/ LocalFoodsMarketingPractices_Highlights.pdf

${ }^{5}$ Gainesville, Florida, Municipal Code§ 30-2.1.

6 "Comprehensive Planning." City of Gainesville. Accessed July 2. 2018. http://www.cityofgainesville.org/PlanningDepartment/ComprehensivePlanning.aspx.

7 “Zoning and Conditional Use Permits." Institute for Local Government. Accessed July 2, 2018. http://www.ca-ilg.org/ hn-online-guide/zoning-and-conditional-use-permits.

8 "Future Land Use Element (FLU)." Charlotte County, Florida Government Portal. Accessed July 2, 2018. https:// www.charlottecountyfl.gov/services/planningzoning/Pages/ CompPlan-Future-Land-Use.aspx.

9 "Land Development Code." Alachua County Growth Management. Accessed July 2, 2018. https://growthmanagement.alachuacounty.us/development/code.

10 "Setback." Legal Dictionary. Accessed July 2, 2018. https:// legal-dictionary.thefreedictionary.com/Setback.

11 "Ordinance." Legal Dictionary. Accessed July 2, 2018. https://legal-dictionary.thefreedictionary.com/ordinance.

12 "Property Topics and Concepts." American Planning Association. Accessed July 2, 2018. https://www.planning. org/divisions/planningandlaw/propertytopics.htm\#Overlay. 
13 "Urban and Regional Planners." Bureau of Labor Statistics. Accessed July 2, 2018. https://www.bls.gov/ooh/lifephysical-and-social-science/urban-and-regional-planners. htm.

14 "Investing in Healthy, Sustainable Places through Urban Agriculture." Report, The Funders' Network, 2011. http:// www.fundersnetwork.org/files/learn/Investing_in_Urban_Agriculture_Final_110713.pdf.

15 "Zoning Changes, Variances, and More." Findlaw. Accessed July 2, 2018. https://realestate.findlaw.com/landuse-laws/zoning-changes-variances-and-more.html.

16 "Planning and Zoning." Urban Ag Law. Accessed July 2, 2018. http://www.urbanaglaw.org/planning-and-zoning/.

17 "Zoning and Conditional Use Permits." Institute for Local Government. Accessed July 2, 2018. http://www.ca-ilg.org/ hn-online-guide/zoning-and-conditional-use-permits.

18 "Policy Workshop". Anthony Olivieri, Florida Food Policy Council. June 2018. 